University of Nebraska - Lincoln

DigitalCommons@University of Nebraska - Lincoln

Publications from USDA-ARS / UNL Faculty

U.S. Department of Agriculture: Agricultural

Research Service, Lincoln, Nebraska

2017

Water use and environmental parameters influence proso millet yield

David C. Nielsen

USDA-ARS, dcnielsen55@gmail.com

Merle F. Vigil

USDA-ARS

Follow this and additional works at: https://digitalcommons.unl.edu/usdaarsfacpub

Nielsen, David C. and Vigil, Merle F., "Water use and environmental parameters influence proso millet yield" (2017). Publications from USDA-ARS / UNL Faculty. 1796.

https://digitalcommons.unl.edu/usdaarsfacpub/1796

This Article is brought to you for free and open access by the U.S. Department of Agriculture: Agricultural Research Service, Lincoln, Nebraska at DigitalCommons@University of Nebraska - Lincoln. It has been accepted for inclusion in Publications from USDA-ARS / UNL Faculty by an authorized administrator of DigitalCommons@University of Nebraska - Lincoln. 


\title{
Water use and environmental parameters influence proso millet yield
}

\author{
David C. Nielsen*, Merle F. Vigil \\ USDA-ARS, Central Great Plains Research Station, Akron, CO 80720, United States
}

\section{A R T I C L E I N F O}

\section{Keywords:}

Proso millet

Water use

Yield

Wind

Temperature

Precipitation

Soil water

\begin{abstract}
A B S T R A C T
Proso millet (Panicum miliaceum L.) is a short-season, drought-tolerant C4 species capable of making use of limited available water supplies and is suitable for dryland crop rotations in the Central Great Plains. Previously published water use/yield production functions for proso millet have slopes lower than reported for other C4 species in this region. The objectives of this experiment were to determine the water-limited yield relationship for proso millet and to identify environmental factors that cause yields to be lower than predicted by the waterlimited yield relationship. Water use and yield data were obtained from a long-term crop rotation experiment conducted under dryland conditions in northeast Colorado from 1995 to 2016. Stepwise linear regression analysis was used to determine important environmental factors influencing yield. The water-limited yield relationship had a slope consistent with other C4 species in this region ( $32.57 \mathrm{~kg} \mathrm{ha}^{-1}$ per mm of water use). A relationship based on growing season water use, plant available soil water at planting, precipitation received from 12 to 18 August, number days in July and August with maximum temperature greater than $36^{\circ} \mathrm{C}$, daily average wind run and maximum wind gust during the week before swathing explained $88 \%$ of yield variability. The results of this analysis suggest that closing the yield gap for proso millet production could likely result from efforts to breed for enhanced shattering resistance and heat tolerance and from production methods that improve precipitation storage efficiency during the non-crop period prior to millet planting and increase available soil water at millet planting.
\end{abstract}

\section{Introduction}

Proso millet is a warm season grass ideally suited to dryland production in the semi-arid Central Great Plains of the United States due to its low water requirement, short growing season (60-90 days), and highly efficient C4 photosynthetic pathway (Lyon et al., 2008; Baltensperger, 1996; Shantz and Piemeisel, 1927). It is used for birdseed and livestock feed within the United States and for human consumption in other countries (Lyon et al., 2008). Production is mainly concentrated in the Great Plains states of Colorado, Nebraska, and South Dakota (Lyon et al., 2008). It is considered a good rotation crop to use following sunflower (Helianthus annuus L.) or corn (Zea mays L.) and prior to winter wheat (Triticum aestivum L.) because of its short growing season, shallow rooting depth $(120 \mathrm{~cm})$, and low water use (Lyon et al., 2008). The short growing season allows farmers to harvest the millet crop in time to plant winter wheat a few weeks later. This is important because in the Central Great Plains winter wheat serves as the base crop upon which most dryland crop rotations are based. Saseendran et al. (2010) used cropping systems simulation modeling to show that proso millet could be an important rotational crop to include with wheat and corn in semi-arid dryland cropping systems. Habiyaremye et al. (2017) provided a comprehensive review of proso millet history, growth, culture, production, uses, genetics, diseases, pests, and adaptability.

There are only a few previously published relationships of proso millet yield response to water use (Table 1). Those relationships have reported slopes ranging from 12.25 to $14.79 \mathrm{~kg} \mathrm{ha}^{-1}$ per mm of water use. These slopes are far below what has been reported for other C4 crops in the Central Great Plains such as corn $\left(25.7 \mathrm{~kg} \mathrm{ha}^{-1} \mathrm{~mm}^{-1}\right.$, Nielsen et al., 2011) and grain sorghum (Sorghum bicolor L. Moench, $30.2 \mathrm{~kg} \mathrm{ha}^{-1} \mathrm{~mm}^{-1}$, Nielsen et al., 2017). Shantz and Piemeisel (1927) considered proso millet to be one of the most water use efficient crops of the 52 species that they collected data on, with a water requirement of $567 \mathrm{~g}$ water per $\mathrm{g}$ of seed produced. This water requirement converts to a yield response of $17.63 \mathrm{~kg} \mathrm{ha}^{-1}$ per mm of water used. However, it should be noted that Shantz and Piemeisel (1927) only reported data for one year, and noted that there was wide year-to-year variation in the water requirement for other species for which they had collected

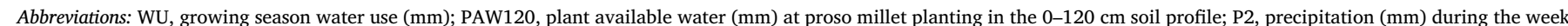

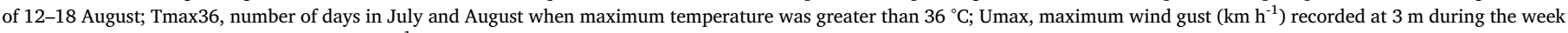
before swathing; WR, average wind run $\left(\mathrm{km} \mathrm{d}^{-1}\right)$ recorded at $3 \mathrm{~m}$ during the week before swathing

* Corresponding author.

E-mail address: david.nielsen@ars.usda.gov (D.C. Nielsen). 
Table 1

Previously reported slopes and offsets for water use/yield production functions ${ }^{\mathrm{a}}$ for proso millet.

\begin{tabular}{|c|c|c|c|c|c|}
\hline Location & $\begin{array}{l}\text { Slope } \\
\mathrm{kg} \mathrm{ha}^{-1} \text { per } \\
\mathrm{mm}\end{array}$ & $\begin{array}{l}\text { Offset } \\
\mathrm{mm}\end{array}$ & Years & $\begin{array}{l}\text { Water Use } \\
\text { Range } \\
\mathrm{mm}\end{array}$ & Source \\
\hline $\begin{array}{l}\text { Northeast } \\
\text { Colorado }\end{array}$ & 12.25 & 131 & 5 & $200-350$ & $\begin{array}{l}\text { Shanahan et al. } \\
\text { (1988) }\end{array}$ \\
\hline $\begin{array}{l}\text { Northeast } \\
\text { Colorado }\end{array}$ & 13.25 & 106 & NA & NA & $\begin{array}{l}\text { Lyon et al. } \\
\text { (2008) }\end{array}$ \\
\hline $\begin{array}{l}\text { Northeast } \\
\text { Colorado }\end{array}$ & 14.79 & 163 & 1 & $185-270$ & $\begin{array}{l}\text { Felter et al. } \\
(2006)\end{array}$ \\
\hline
\end{tabular}

${ }^{\mathrm{a}}$ Form of production function is yield $\left[\mathrm{kg} \mathrm{ha}^{-1}\right]=$ slope $\mathrm{X}$ (water use $[\mathrm{mm}]-$ offset).

multi-year data. In addition to these previously reported water useyield relationships for proso millet are the findings of Lyon et al. (1995) and Felter et al. (2006) who showed the strong influence of available soil water at planting on proso millet seed yield. Nelson and Fenster (1983) used stepwise multiple regression to determine that June rainfall was the most influential parameter affecting (positively) proso millet stand count and July rainfall was the most influential parameter affecting (positively) proso millet yield.

Several researchers have reported on the detrimental effects of water stress on proso millet yield for the period shortly before and after anthesis (Seghatoleslami et al., 2008; Emendack et al., 2011; Matsuura et al., 2012). Although there appear to be no reported field or greenhouse studies of the effects of high temperatures on proso millet yield, Habiyaremye et al. (2017) suggested that temperatures above $30{ }^{\circ} \mathrm{C}$ stopped proso millet vegetative growth and flowering. Additionally, lack of sufficient precipitation at planting or heavy rains following planting can both result in poor plant stands leading to greatly reduced millet yields (Lyon et al., 2008).

The previously reported responses of proso millet seed yield to growing season water use are much lower than would be expected for a C4 species. Hence, the objectives of this experiment were to: 1) define a water-limited yield relationship for proso millet for the central Great Plains region of the U.S. and 2) determine environmental factors that cause grain yield to fall below this water-limited yield relationship. The results should help to guide both plant breeders and agronomic managers in determining plant characteristics and management practices that maintain yield potential under the varying environmental conditions of the Central Great Plains.

\section{Materials and methods}

Proso millet water use and yield data were collected from 1995 to 2016 as part of an ongoing long-term alternative crop rotation experiment conducted at the USDA-ARS Central Great Plains Research Station $\left(40^{\circ} 09^{\prime} \mathrm{N}, 103^{\circ} 09^{\prime} \mathrm{W}, 1383 \mathrm{~m}\right.$ elevation above sea level) located $6.4 \mathrm{~km}$ east of Akron, CO. The soil was a Weld silt loam (Aridic Argiustolls) (https://soilseries.sc.egov.usda.gov/OSD_Docs/W/WELD.html, accessed 19 April 2017). The long-term experiment was established in the fall of 1990 and has been previously described by Anderson et al. (1999), Bowman and Halvorson (1997), and Nielsen and Vigil (2010). Proso millet was grown in 18 different crop rotations (2-yr, 3-yr, 4-yr, opportunity cropping). Variation in available soil water at planting and millet water use in a given year occurred because of differences in water use by the various preceding crops, which were wheat, corn, sunflower, safflower (Carthamus tinctorius L.), or pea (Pisum sativa L.). Each phase of each rotation appeared every year. Individual plot size was 9.1 by $30.5 \mathrm{~m}$ with east-west row direction. Each year of the study had three replications of each rotation.

All rotations were managed under no tillage management with weed control during both cropped and non-crop periods consisting of contact and residual herbicide applications applied at recommended rates. Herbicides used in the rotations were glyphosate $(N$ phosphonomethyl)glycine); paraquat (1,1'-dimethyl-4,4'-bipyridinium dichloride); atrazine (1-chloro-3-ethylamino-5-isopropylamino-2,4,6triazine); 2,4-D (2,4-dichlorophenoxyacetic acid); dicamba (3,6-dichloro-2-methoxybenzoic acid); fluroxypyr ([4-amino-3,5-dichloro-6fluoro-2-pyridinyl)oxy] acetic acid); imazamox (2-[4,5-dihydro-4-methyl-4-(1-methyethyl)-5-oxo-1H-imidazol-2-yl]-5-(methoxymethyl)-3pyridinecarboxylic acid); and carfentrazone (ethyl-alpha-2-dichloro-5[4-(difluoromethyl)-4,5-dihydro-3-methyl-5-oxo-1H-,2,4-triazol-1-yl]4-fluorobenzenepropanoate).

Dates of millet planting, swathing, and harvest are given in Table 2 . Row spacing was $0.19 \mathrm{~m}$. Millet was planted at $16.8 \mathrm{~kg} \mathrm{ha}^{-1}$. Nitrogen and phosphorus were applied at planting at rates shown in Table 2. Harvest sample areas were approximately $28-35 \mathrm{~m}^{2}$. Millet grain yield is reported at $120 \mathrm{~g} \mathrm{~kg}^{-1}$ moisture content.

Soil water was measured at two locations near the center of each plot at 0.3-m intervals with a neutron probe (Model 503 Hydroprobe, CPN International, Martinez, CA) via the installation of neutron probe access tubes in each plot. The depth intervals were $0.3-0.6 \mathrm{~m}$, $0.6-0.9 \mathrm{~m}, 0.9-1.2 \mathrm{~m}, 1.2-1.5 \mathrm{~m}$, and $1.5-1.8 \mathrm{~m}$, with the neutron probe source centered on each interval. Volumetric soil water in the 0.0-0.3 m surface layer was determined using time-domain reflectometry (Trase System I, Soil Moisture Equipment Corp., Santa Barbara, CA) with 0.3-m waveguides installed vertically approximately $40 \mathrm{~cm}$ from the neutron probe measurement site to average the water content over the entire layer. The neutron probe was calibrated against gravimetric soil water samples taken in the plot area. Gravimetric soil water was converted to volumetric water by multiplying by the soil bulk density for each depth. Bulk density was determined from the dry weight of the soil cores ( $38 \mathrm{~mm}$ diameter by $300 \mathrm{~mm}$ length) taken from each depth at the time of neutron probe access tube installation.

Available soil water at planting was computed by subtracting the lower limit of water availability at each soil water measurement depth (Ritchie, 1981; Ratliff et al., 1983) from the calculated volumetric water at that depth and multiplying the difference by the soil layer thickness $(0.3 \mathrm{~m})$. The lower limit of water availability at each of the six measurement depth intervals $(0.100,0.129,0.087,0.067,0.086$, $0.119 \mathrm{~m}^{3} \mathrm{~m}^{-3}$, respectively, for the $0.0-0.3 \mathrm{~m}$ surface layer down to the $1.5-1.8 \mathrm{~m}$ lowest layer) was determined previously in the plot area as the lowest volumetric water value observed for each crop over a period of several years (Nielsen et al., 2011). The individual values of available water at each of the top four depths in each plot were summed to give the profile plant available soil water at each of the two measurement locations in each plot and those two values were averaged to give one value of available soil water for each plot.

Full season water use was calculated as the difference between soil water readings at planting and swathing plus growing season precipitation. Precipitation was manually measured daily at two locations in the plot area and averaged. Runoff and deep percolation were assumed to be negligible. This was considered a reasonable assumption as the slope in the plot area was $<1 \%$ and visual observations in the plot area following heavy rains did not show evidence of runoff. Also, analysis of the soil water changes over time at the three deepest measurement layers did not show any evidence of increasing soil water content that would indicate deep percolation. Other weather parameters that were measured at a site approximately $250 \mathrm{~m}$ from the experimental area were daily pan evaporation from a Class A evaporation pan, air temperature at a height of $1.5 \mathrm{~m}$ above an unirrigated grass surface, and daily average wind run and daily maximum wind gust at a height of $3.0 \mathrm{~m}$ above the grass surface.

Swathing of millet was performed when the top of the main head had mature seed, as recommended by Lyon et al. (2008) and Berglund (2007). Harvest with a grain combine equipped with a pickup head occurred an average of nine days after swathing (Table 2) during which time the grain dried in the windrow created with the swather. Swathing 
Table 2

Cultural operations and heading dates for proso millet grown at Akron, CO, 1995-2016.

\begin{tabular}{|c|c|c|c|c|c|c|c|c|}
\hline \multirow[t]{2}{*}{ Year } & \multirow[t]{2}{*}{ Planting Date } & \multirow[t]{2}{*}{ Heading Date } & \multirow[t]{2}{*}{ Fully Headed Date } & \multirow[t]{2}{*}{ Swathing Date } & \multirow[t]{2}{*}{ Harvest Date } & \multirow[t]{2}{*}{ Variety } & \multirow{2}{*}{$\frac{\text { Nitrogen Applied }}{\mathrm{kg} \mathrm{N} \mathrm{ha}^{-1}}$} & \multirow{2}{*}{$\begin{array}{l}\text { Phosphorus Applied } \\
\mathrm{kg} \mathrm{P}_{2} \mathrm{O}_{5} \mathrm{ha}^{-1}\end{array}$} \\
\hline & & & & & & & & \\
\hline 1995 & 19 June $^{a}$ & 7 Aug & 14 Aug. & 7 Sep. & $18 \mathrm{Sep}$ & Sunup & 45 & 0 \\
\hline 1996 & 4 June & 22 July & 8 Aug. & 3 Sep. & 6 Sep. & Sunup & 34 & 0 \\
\hline 1997 & 19 June & 25 July & 12 Aug. & 7 Sep. & 10 Sep. & Sunup & 34 & 17 \\
\hline 1998 & 7July ${ }^{\mathrm{a}}$ & 3 Aug. & N/A & 8 Sep. & 14 Sep. & Sunup & 45 & 17 \\
\hline 1999 & 8 June & 19 July & 10 Aug. & 2 Sep. & 20 Sep. & Sunup & 45 & 17 \\
\hline 2000 & 6 June & 13 July & 7 Aug. & 7 Sep. & 12 Sep. & Sunup & 45 & 17 \\
\hline 2001 & 25 June & 6 Aug. & 24 Aug. & 12 Sep. & 20 Sep. & Huntsman & 45 & 17 \\
\hline 2002 & 12 June & $\mathrm{N} / \mathrm{A}^{\mathrm{b}}$ & N/A & N/A & N/A & Sunup & 90 & 22 \\
\hline 2003 & 20 June & 28 July & 13 Aug. & 27 Aug. & 5 Sep. & Sunup & 56 & 22 \\
\hline 2004 & 7 June & N/A & 8 Aug. & 17 Sep. & 24 Sep. & Sunup & 50 & 17 \\
\hline 2005 & 10 June & 15 July & 26 July & 2 Sep. & 12 Sep. & Sunup & 56 & 20 \\
\hline 2006 & 8 June & N/A & 2 Aug. & 28 Aug. & 15 Sep. & Huntsman & 45 & 17 \\
\hline 2007 & 21 June & 16 July & N/A & 7 Sep. & 13 Sep. & Huntsman & 45 & 17 \\
\hline 2008 & 20 June & N/A & 4 Aug. & 17 Sep. & 29 Sep. & Huntsman & 39 & 17 \\
\hline 2009 & 29 June & N/A & 1 Aug. & 11 Sep. & 1 Oct. & Huntsman & 39 & 17 \\
\hline 2010 & 1 June & 18 July & 23 July & 30 Aug. & 7 Sep. & Huntsman & 39 & 17 \\
\hline 2011 & 9 June & 25 July & 29 July & 31 Aug. & 9 Sep. & Huntsman & 39 & 0 \\
\hline 2012 & 30 May & N/A & N/A & 13 Sep. & 20 Sep. & Huntsman & 39 & 17 \\
\hline 2013 & 3 June & 1 Aug. & 5 Aug. & 3 Sep. & 9 Sep. & Huntsman & 39 & 17 \\
\hline 2014 & 5 June & N/A & N/A & 4 Sep. & 17 Sep. & Huntsman & 39 & 17 \\
\hline 2015 & 25 June $^{\mathrm{a}}$ & 31 July & N/A & 10 Sep. & 14 Sep. & Huntsman & 39 & 17 \\
\hline 2016 & 16 June & N/A & 8 Aug. & 6 Sep. & 12 Sep. & Huntsman & 39 & 17 \\
\hline Average & 14 June & 25 July & 6 Aug. & 6 Sep. & 15 Sep. & & & \\
\hline
\end{tabular}

Planting rate: $11 \mathrm{~kg} \mathrm{ha}^{-1}$ (1995-1996); $13 \mathrm{~kg} \mathrm{ha}^{-1}$ (1997); $19 \mathrm{~kg} \mathrm{ha}^{-1}$ (2000); $17 \mathrm{~kg} \mathrm{ha}^{-1}$ (1998-1999, 2001-2016).

${ }^{a}$ Reseeded.

b No heading and harvest in Sept 2002 due to severe drought; limited or no observations of heading in 1998, 2004, 2006, 2007, 2008, $2009,2012,2014,2015,2016$.

is a recommended practice as even a small wind near the end of the growing season can cause considerable shattering and grain loss (Lyon et al., 2008). The two varieties of millet grown over the 22 years of this experiment, Sunup and Huntsman (Nelson, 1990; Baltensperger et al., 1995), were considered to be varieties with less susceptibility to seed shattering and lodging (Lyon et al., 2008).

Water use and yield data were analyzed by linear regression for each year of the study and for various combinations of years. The waterlimited yield potential (French and Schultz, 1984) was determined by plotting all of the proso millet grain yield data collected over the 22 years of the study against the measured water use and then fitting a "frontier line" to the data (Angus and van Herwaarden, 2001; Sadras and Angus, 2006; Kirkegaard and Hunt, 2010). The frontier line was eye-fit to the left edge of the data points in the yield vs. water use scatter plot and then moved to the right, parallel to itself until 10 points were intercepted and those 10 points were used to determine the linear regression equation that defined the water-limited yield relationship (Nielsen et al., 2015). All regressions were performed with Statistix 10 software (Analytical Software, Tallahassee, FL).

A number of environmental factors that were thought to influence proso millet yields are listed in Table 3. Growing season water use and plant available water at millet planting were included because of their previously documented influence on yield (Lyon et al., 1995; Shanahan et al., 1988; Felter et al., 2006; Lyon et al., 2008). The available soil water at millet planting was calculated for only the $0-120 \mathrm{~cm}$ layer because rooting and soil water extraction are primarily only seen in this depth interval for proso millet (Lyon et al., 2008; Hablyaremye et al., 2017). The weekly pan evaporation parameters were included as important parameters because they quantify evaporative demand. Evaporative demand has been acknowledged as influencing the slope of the water use/yield relationship, with increasing evaporative demand resulting in a decrease in slope (Tanner and Sinclair, 1983; Musick et al., 1994; Stewart et al., 1977; Shantz and Piemeisel, 1927). The weekly precipitation occurring in August and the number of days in July and August with maximum temperatures exceeding several threshold temperatures were included because of the suspected detrimental effects that water stress and high temperatures could have on yield during reproductive and grain filling stages. The daily average wind run and the maximum wind gust during the week prior to swathing were included in an attempt to quantify conditions that could lead to seed loss through shattering due to continuous shaking of the seed head (wind run) or due to a more vigorous singular wind event (wind gust). These factors were analyzed as to their influence on millet yield by including them in a stepwise linear regression analysis using the Statistix 10 software. The stepwise regression procedure was set to always include growing season crop water use and plant available soil water at planting (0-120 cm soil profile) as those two parameters had been previously shown to be highly correlated with millet yield (Lyon et al., 1995; Shanahan et al., 1988; Felter et al., 2006; Lyon et al., 2008). While it could be argued that there is no reason to include plant available soil water at planting as a separate variable because it is already included in the growing season crop water use parameter, we felt that including the plant available water at planting would add important information to the regression analysis regarding potential timing of water stress that would not be available if only the seasonal water use were included. While plant available water at planting is indeed included in seasonal water use, its inclusion as a separate variable imparts some different information relative to timing of water use and potential development of stresses influencing yield. Large values of plant available water at planting generally indicate water at deeper depths in the soil profile which potentially can lead to less water stress during reproductive stages later in the growing season depending on timing of within season precipitation.

While we chose to use stepwise linear regression to determine the relationship between environmental factors and proso millet yield, readers should be aware that there are other methods that could be used such as crop simulation modeling. Crop simulation modeling has been used for sensitivity analysis to determine crop yield responses to varying environmental conditions (Grossi et al., 2015), but use of such models requires relatively large data sets of yield, yield components, leaf area development, biomass accumulation, and growth stage observations over a range of environmental conditions and management 
Table 3

Environmental factors that may have an important influence on proso millet yield and which were analyzed by stepwise linear regression.

\begin{tabular}{|c|c|}
\hline Abbreviation & Description \\
\hline PE1 & Pan Evaporation (mm) from 1 to 7 July \\
\hline PE2 & Pan Evaporation (mm) from 8 to 14 July \\
\hline PE3 & Pan Evaporation (mm) from 15 to 21 July \\
\hline PE4 & Pan Evaporation (mm) from 22 to 28 July \\
\hline PE5 & Pan Evaporation (mm) from 29 July to 4 August \\
\hline PE6 & Pan Evaporation (mm) from 5 to 11 August \\
\hline PE7 & Pan Evaporation (mm) from 12 to 18 August \\
\hline PE8 & Pan Evaporation (mm) from 19 to 25 August \\
\hline PE9 & Pan Evaporation (mm) from 26 August to 1 September \\
\hline Water Use & Water use from planting to swathing (mm) \\
\hline PAW120 & $\begin{array}{l}\text { Plant available water in the } 0-120 \mathrm{~cm} \text { soil profile at planting } \\
(\mathrm{mm})\end{array}$ \\
\hline P1 & Precipitation (mm) from 5 to 11 August \\
\hline P2 & Precipitation (mm) from 12 to 18 August \\
\hline P3 & Precipitation (mm) from 19 to 25 August \\
\hline P4 & Precipitation (mm) from 26 August to 1 September \\
\hline P1-2 & Precipitation (mm) from 5 to 18 August \\
\hline $\operatorname{Tmax} 26$ & $\begin{array}{l}\text { Number of days in July and August with maximum temperature } \\
\text { greater than } 26 \mathrm{C}\end{array}$ \\
\hline $\operatorname{Tmax} 28$ & $\begin{array}{l}\text { Number of days in July and August with maximum temperature } \\
\text { greater than } 28 \mathrm{C}\end{array}$ \\
\hline $\operatorname{Tmax} 30$ & $\begin{array}{l}\text { Number of days in July and August with maximum temperature } \\
\text { greater than } 30 \mathrm{C}\end{array}$ \\
\hline Tmax32 & $\begin{array}{l}\text { Number of days in July and August with maximum temperature } \\
\text { greater than } 32 \mathrm{C}\end{array}$ \\
\hline $\operatorname{Tmax} 34$ & $\begin{array}{l}\text { Number of days in July and August with maximum temperature } \\
\text { greater than } 34 \mathrm{C}\end{array}$ \\
\hline $\operatorname{Tmax} 36$ & $\begin{array}{l}\text { Number of days in July and August with maximum temperature } \\
\text { greater than } 36 \mathrm{C}\end{array}$ \\
\hline $\operatorname{Tmax} 38$ & $\begin{array}{l}\text { Number of days in July and August with maximum temperature } \\
\text { greater than } 38 \mathrm{C}\end{array}$ \\
\hline $\operatorname{Tmax} 40$ & $\begin{array}{l}\text { Number of days in July and August with maximum temperature } \\
\text { greater than } 40 \mathrm{C}\end{array}$ \\
\hline Umax & $\begin{array}{l}\text { Maximum wind gust measured at } 3 \mathrm{~m} \text { height during the week } \\
\text { prior to swathing }\left(\mathrm{km} \mathrm{h}^{-1}\right)\end{array}$ \\
\hline WR & $\begin{array}{l}\text { Daily average wind run during the week prior to swathing } \\
\left(\mathrm{km} \mathrm{d}^{-1}\right)\end{array}$ \\
\hline
\end{tabular}

practices for model calibration and validation for a given soil type (Ma et al., 2011, 2012). We determined that for our purposes it would be more efficient to use our data set with stepwise linear regression than to use it for calibrating and validating a crop simulation model.

\section{Results}

\subsection{Yield $v$ s water use}

The scatter plot of yield vs. water use (Fig. 1, upper panel) shows wide variation in the response from year to year. Of the 22 data sets shown from 1995 to 2016, only eight showed linear regressions that were statistically significant $(\mathrm{P}<0.10$, Table 4$)$. For those eight relationships the regression slopes ranged from $11.77 \mathrm{~kg} \mathrm{ha}^{-1} \mathrm{~mm}^{-1}$ in 1996 to $35.37 \mathrm{~kg} \mathrm{ha}^{-1} \mathrm{~mm}^{-1}$ in 1997 . The water-limited frontier line was determined to be

Yield $\left[\mathrm{kg} \mathrm{ha}^{-1}\right]=32.57 \mathrm{X}$ (Water Use $\left.[\mathrm{mm}]-114\right)$

The slope of this water-limited frontier line is similar to that reported previously for grain sorghum by Nielsen and Vigil (2017) ( $30.2 \mathrm{~kg} \mathrm{ha}^{-1}$ per mm of water use) and seems to be appropriate for a C4 species grown in this region. However, our frontier line slope is much greater than the slope of the production function reported by Shanahan et al. (1988) for proso millet data $\left(12.25 \mathrm{~kg} \mathrm{ha}^{-1}\right.$ per mm of water use) collected over a 5-yr period at the same location. As seen in Fig. 1, there are a great many years in which the yields produced by a given water use fall far below the water-limited yield frontier line.

\subsection{Stepwise linear regression determination of yield-influencing environmental factors}

Table 5 shows the stepwise linear regression analysis of the factors listed in Table 3 that were suspected to influence proso millet yield. This analysis was performed using only data from 1995 to 2009. The data from 2010 to 2016 were used to verify the regression model chosen to best represent the data. As stated earlier, the stepwise linear regression analysis stipulated that water use and plant available water at planting would always be parameters in the regression model because of previous research that indicated the strong influence that those two factors had on proso millet yield.

The best regression determined by the stepwise procedure contained nine of the 26 environmental factors listed in Table 3 that we suspected could have an influence on millet yield. Those nine factors were water use and plant available water at planting (forced to be in the regression), precipitation during 12-18 August, and number of days in July and August when daily maximum temperature was greater than $30{ }^{\circ} \mathrm{C}$ (which all increased yield); and pan evaporation during 15-21 July, number of days in July and August when daily maximum temperature was greater than $28^{\circ} \mathrm{C}$, number of days in July and August when daily maximum temperature was greater than $36^{\circ} \mathrm{C}$, maximum wind gust during the week before swathing, and average daily wind run during the week before swathing (which all decreased yield). The model accounted for $91.3 \%$ of the variation in yield.

After viewing the results of the stepwise linear regression analysis, we decided to try three other models that had most of the important parameters but which would be somewhat simpler. The results for those regressions are shown in the last three lines of Table 4 (noted in the Step column as $\mathrm{M}$ and as Equations 11, 12, and 13). The $\mathrm{R}^{2}$ value for Equation 12 regression on the second $\mathrm{M}$ line was 0.884 , and that regression predicted the measured yields well for the 1995-2009 period (Fig. 2, upper panel). The $\mathrm{R}^{2}$ was not greatly different from the regressions identified at steps $6,7,8$ of the stepwise linear regression analysis and on the third $M$ line of Table 5, Equation $13\left(\mathrm{R}^{2}\right.$ ranging from 0.888 to 0.898 ). These other four regressions all required more parameters (seven to eight) than the six-parameter regression identified as Equation 12 in Table 4, which is defined as

Yield $=7510+4.47 * \mathrm{WU}+9.05 * \mathrm{PAW} 120+23.78 * \mathrm{P} 2-$

109.5*Tmax36-88.52*Umax - 9.56*WR

where Yield $=$ proso millet grain yield $\left(\mathrm{kg} \mathrm{ha}^{-1}\right)$

$\mathrm{WU}=$ growing season water use $(\mathrm{mm})$

PAW120 = plant available water $(\mathrm{mm})$ at proso millet planting in the $0-120 \mathrm{~cm}$ soil profile

$\mathrm{P} 2=$ precipitation $(\mathrm{mm})$ during the week of $12-18$ August

Tmax36 = number of days in July and August when maximum temperature was greater than $36^{\circ} \mathrm{C}$

Umax $=$ maximum wind gust $\left(\mathrm{km} \mathrm{h}^{-1}\right)$ recorded at $3 \mathrm{~m}$ during the week before swathing

$\mathrm{WR}=$ average daily wind run $\left(\mathrm{km} \mathrm{day}^{-1}\right)$ recorded at $3 \mathrm{~m}$ during the week before swathing

The regression coefficients can be seen as having the following biological meanings. The constant $\left(7510 \mathrm{~kg} \mathrm{ha}^{-1}\right)$ can be seen as being close to an environmental potential yield for proso millet in this region. Proso millet yield increases by $4.47 \mathrm{~kg} \mathrm{ha}^{-1}$ for each $\mathrm{mm}$ of water use that occurs and also increases $9.05 \mathrm{~kg} \mathrm{ha}^{-1}$ for each $\mathrm{mm}$ of available water that exists in the soil profile at planting. The $\mathrm{P} 2$ parameter can be viewed as the marginal value of rainfall during the specific time of 


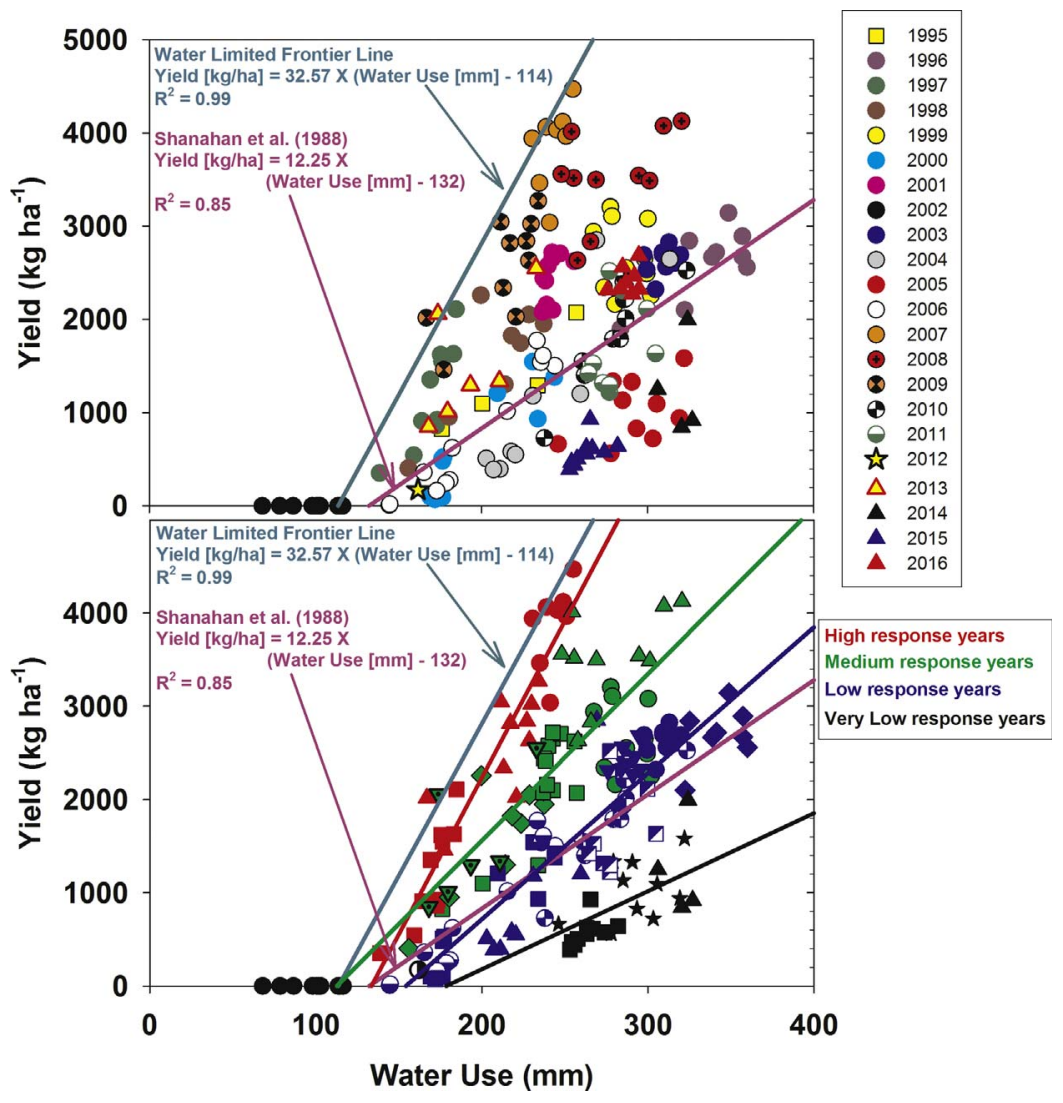

Fig. 1. Water use and yield of proso millet at Akron, CO (1995-2016) by year (upper panel) and by water use/yield response category (lower panel).
Table 4

Slopes and offsets for water use/yield production function ${ }^{\mathrm{a}}$ for proso millet as determined by linear regression of grain yield on water use at Akron, CO, 1995-2016. Values for coefficient of determination $\left(\mathrm{R}^{2}\right)$ and probability that regression is significant $(\mathrm{P})$ are also given.

\begin{tabular}{llllc}
\hline Year & $\begin{array}{l}\text { Slope } \\
\mathrm{kg} \mathrm{ha}^{-1} \text { per mm }\end{array}$ & $\begin{array}{l}\text { Offset } \\
\mathrm{mm}\end{array}$ & $\mathrm{R}^{2}$ & $\mathrm{P}>\mathrm{F}$ \\
\hline 1995 & 13.96 & 122 & 0.87 & 0.07 \\
1996 & 11.77 & 115 & 0.54 & 0.02 \\
1997 & 35.37 & 136 & 0.73 & $<0.01$ \\
1998 & -2.23 & 1215 & 0.00 & 0.94 \\
1999 & -9.09 & 586 & 0.08 & 0.40 \\
2000 & 16.68 & 156 & 0.81 & $<0.01$ \\
2001 & 22.00 & 131 & 0.25 & 0.14 \\
$2002^{\mathrm{b}}$ & & & & \\
2003 & 6.88 & -74 & 0.11 & 0.34 \\
2004 & 23.92 & 189 & 0.86 & $<0.01$ \\
2005 & 6.61 & 138 & 0.20 & 0.20 \\
2006 & 17.94 & 156 & 0.93 & $<0.01$ \\
2007 & 25.41 & 91 & 0.26 & 0.16 \\
2008 & 9.12 & -109 & 0.24 & 0.15 \\
2009 & 19.03 & 79 & 0.57 & 0.01 \\
2010 & 22.50 & 195 & 0.80 & $<0.01$ \\
2011 & 12.51 & 144 & 0.13 & 0.35 \\
$2012^{\mathrm{b}}$ & & & & \\
2013 & 16.24 & 100 & 0.37 & 0.20 \\
2014 & -13.57 & 405 & 0.63 & 0.21 \\
2015 & 8.02 & 192 & 0.24 & 0.15 \\
2016 & 7.33 & -42 & 0.11 & 0.43 \\
\hline
\end{tabular}

${ }^{\text {a }}$ Form of production function is Yield $\left[\mathrm{kg} \mathrm{ha}^{-1}\right]=$ slope $\mathrm{X}$ (Water Use [mm] - offset).

b No regression for 2002 because all yield values were zero due to severe drought; no regression for 2012 because only one point available due to severe drought.

12-18 August, when rain during this week serves to increase yield by $23.78 \mathrm{~kg} \mathrm{ha}^{-1}$ for each $\mathrm{mm}$ received. Tmax36 quantifies the marginal loss of yield due to high temperatures in July and August where $109.5 \mathrm{~kg} \mathrm{ha}^{-1}$ of yield is lost for each day in those two months when the maximum air temperature is greater than $36^{\circ} \mathrm{C}$. The two wind parameters during the week before swathing appear to quantify seed shattering yield losses that can occur because of high gusts (Umax, $88.52 \mathrm{~kg} \mathrm{ha}^{-1}$ yield loss for every $\mathrm{km} \mathrm{h}^{-1}$ of the maximum wind gust) and because of persistent windy conditions during the week before swathing (WR, $9.56 \mathrm{~kg} \mathrm{ha}^{-1}$ yield loss for every $\mathrm{km}$ of wind that passes the field on a daily average basis).

We tested the applicability of this six-parameter regression model with data from 2010 to 2016. Fig. 2 (lower panel) shows the yields predicted with the regression model plotted against the measured yields for those seven years (half-filled circle symbols). Except for the data collected in 2013 and 2015, the six-parameter regression model predicted millet yields with about the same scatter around the 1:1 line as seen for the data from 1995 to 2009 used to generate the model. The measured yields in 2015 were much lower than predicted due to a devastating hail storm that occurred on 1 August 2015. The much lower than predicted yields seen in 2013 are likely due to poor plant stands, although we did not note any conditions at planting or shortly thereafter that would have resulted in a poor stand. Our measurements of leaf area index on 7 August 2013 averaged only $1.43 \mathrm{~m}^{2} \mathrm{~m}^{-2}$, which was lower than we would have expected at that time of year (heading). Photographs of the plots taken during the season also showed sporadic plant stands. Also, the measured values of the six regression model parameters recorded in 2013 (Table 3) would lead to high yield predictions (only 4 days in July and August with Tmax greater than $36^{\circ} \mathrm{C}$, second highest 12-18 August precipitation [53 mm], second lowest wind gust in the week prior to swathing $\left[40.4 \mathrm{~km} \mathrm{~h}^{-1}\right.$ ], below average daily wind run in the week prior to swathing $\left[273.5 \mathrm{~km} \mathrm{day}^{-1}\right]$ ) had there been a good stand of millet. (Note: the predicted vs measured yield for 2012 is not plotted in Fig. 2 because the predicted yield for that year $\left(-1429 \mathrm{~kg} \mathrm{ha}^{-1}\right)$ could not be plotted on the existing scale used in the figure. The very large negative yield predicted by the regression model for 2012 was largely due to the 21 days in July and August with Tmax greater than $36^{\circ} \mathrm{C}$, only $1 \mathrm{~mm}$ of precipitation 
Table 5

Stepwise Linear Regression results (regression coefficients and $\mathrm{R}^{2}$ ) for proso millet yield regressed on water use and environmental parameters at Akron, CO, $1995-2009$.

\begin{tabular}{|c|c|c|c|c|c|c|c|c|c|c|c|c|c|c|}
\hline Step & Equation & $\begin{array}{l}\text { Constant } \\
\mathrm{kg} \mathrm{ha}^{-1}\end{array}$ & $\begin{array}{l}\text { WU } \\
\mathrm{kg} \mathrm{ha}^{-1}\end{array}$ & $\begin{array}{l}\text { PAW120 } \\
\mathrm{mm}^{-1}\end{array}$ & PE3 & P1 & $\mathrm{P} 2$ & P1-2 & $\begin{array}{l}\text { Tmax28 } \\
\mathrm{kg} \mathrm{ha}^{-1} \mathrm{~d}\end{array}$ & $\operatorname{ay}^{-1}$ Tmax30 & Tmax36 & $\begin{array}{l}\operatorname{Umax} \\
\mathrm{kg} \mathrm{ha}^{-1}\left(\mathrm{~km} \mathrm{~h}^{-1}\right)^{-1}\end{array}$ & $\begin{array}{l}\text { WR } \\
\mathrm{kg} \mathrm{ha}^{-1}\left(\mathrm{~km} \mathrm{~d}^{-1}\right)^{-1}\end{array}$ & $\mathrm{R}^{2}$ \\
\hline 1 & 1 & -934 & 8.25 & 5.83 & & & & & & & & & & 0.377 \\
\hline 2 & 2 & -741 & 1.16 & 11.16 & & & & 16.53 & & & & & & 0.614 \\
\hline 3 & 3 & 92 & -0.49 & 13.58 & & & & 17.49 & & & -95.3 & & & 0.751 \\
\hline 4 & 4 & 2707 & 1.17 & 13.45 & & & & 14.50 & & & -112.7 & -53.66 & & 0.840 \\
\hline 5 & 5 & 2715 & 2.35 & 11.87 & & & 13.13 & 9.09 & & & -111.6 & -53.98 & & 0.861 \\
\hline 6 & 6 & 6652 & 3.37 & 10.21 & & & 19.09 & 3.79 & & & -110.2 & -81.17 & -7.97 & 0.888 \\
\hline 7 & 7 & 8602 & 3.24 & 9.72 & -8.80 & & 27.05 & 1.09 & & & -100.0 & -86.18 & -10.94 & 0.898 \\
\hline 8 & 8 & 8936 & 3.50 & 9.40 & -9.36 & & 28.70 & & & & -99.2 & -88.29 & -11.51 & 0.898 \\
\hline 9 & 9 & 7765 & 4.25 & 8.87 & -8.17 & & 28.49 & & & 18.50 & -121.1 & -88.28 & -10.13 & 0.903 \\
\hline 10 & 10 & 9065 & 4.53 & 9.92 & -4.71 & & 27.14 & & -65.97 & 75.64 & -141.2 & -98.93 & -10.94 & 0.913 \\
\hline M & 11 & 6490 & 3.90 & 11.51 & & 8.67 & & & & & -112.1 & -86.75 & -6.92 & 0.763 \\
\hline M & 12 & 7510 & 4.47 & 9.05 & & & 23.78 & & & & -109.5 & -88.52 & -9.56 & 0.884 \\
\hline M & 13 & 6651 & 3.38 & 10.21 & & 3.79 & 22.87 & & & & -110.2 & -81.17 & -7.97 & 0.888 \\
\hline
\end{tabular}

$\mathrm{M}$ = manually entered regression parameters (results are not from the stepwise linear regression analysis).

$\mathrm{WU}=$ growing season water use.

PAW120 = Plant available water $(\mathrm{mm})$ at proso millet planting in the $0-120 \mathrm{~cm}$ soil layer.

PE3 = Pan evaporation (mm) 15-21 July.

$\mathrm{P} 1$ = precipitation (mm) 5-11 August.

P2 = precipitation (mm) 12-18 August.

P1-2 = precipitation (mm) 5-18 August.

Tmax28 = number of days in July and August when maximum temperature was greater than $28{ }^{\circ} \mathrm{C}$.

Tmax30 = number of days in July and August when maximum temperature was greater than $30^{\circ} \mathrm{C}$.

Tmax36 = number of days in July and August when maximum temperature was greater than $36^{\circ} \mathrm{C}$.

$\mathrm{Umax}=$ Maximum wind gust $\left(\mathrm{km} \mathrm{h}^{-1}\right)$ recorded at $3 \mathrm{~m}$ during week before swathing.

$\mathrm{WR}=$ average wind run $\left(\mathrm{km} \mathrm{h}^{-1}\right.$ day $\left.^{-1}\right)$ recorded at $3 \mathrm{~m}$ during week before swathing.

WU and PAW120 were forced to be in the stepwise linear regression analysis. The P value to enter or exit the regression was set to 0.05

received during 12-18 August, and relatively high winds during the week before swathing, Table 6.) Even though visually the spread of the data shown in the lower panel of Fig. 2 for years 2010, 2011, 2014, and 2016 appears to be similar to the spread for the years 1995-2009, the regression model performance was considerably worse as quantified by the root mean square error (380 vs $462 \mathrm{~kg} \mathrm{ha}^{-1}$ ) and Willmott's D modified index of agreement (0.84 vs 0.64 ; Willmott, 1984).

We visually divided the water use/yield data into four groups with high, medium, low, and very low yield responses to water use (Fig. 1, lower panel; Table 6). Years 1997, 2007, and 2009 defined a high yield response to water use (regression slope of $33.62 \mathrm{~kg} \mathrm{ha}^{-1} \mathrm{~mm}^{-1}$ ) that was not different $(\mathrm{P}=0.78)$ from the water-limited frontier line slope $\left(32.57 \mathrm{~kg}^{-1} \mathrm{~mm}^{-1}\right)$. Years 1995, 1998, 1999, 2001, 2008, and 2013 defined a medium yield response to water use (regression slope of $17.88 \mathrm{~kg} \mathrm{ha}^{-1} \mathrm{~mm}^{-1}$ ). A low response (regression slope of $15.66 \mathrm{~kg} \mathrm{ha}^{-1} \mathrm{~mm}^{-1}$ ) was defined by years 1996, 2000, 2003, 2004, $2006,2010,2011$, and 2016. This water production function slope was similar to the response previously defined by Shanahan et al. (1988) of $12.25 \mathrm{~kg} \mathrm{ha}^{-1} \mathrm{~mm}^{-1}$. A very low yield response to water use (regression slope of $8.37 \mathrm{~kg} \mathrm{ha}^{-1} \mathrm{~mm}^{-1}$ ) was seen for years 2005, 2012, 2014, and 2015. All five of these regressions (frontier line, high response, medium response, low response, very low resopsne) were statistically different from one another $(\mathrm{P}<0.01$ for all comparisons of regression slopes and intercepts) except for the frontier line and high response regressions which had similar slopes $(\mathrm{P}=0.78)$ but different intercepts $(\mathrm{P}<0.01)$ and the medium and low response regressions which also had similar slopes $(\mathrm{P}=0.12)$ but different intercepts $(\mathrm{P}<0.01)$.

We plotted the linear regression slopes shown in Table 6 for each water use/yield response group against the average values of number of days in July and August with Tmax $>36^{\circ} \mathrm{C}$, precipitation during the week of 12-18 August, maximum wind gust during the week before swathing, daily average wind run the week before swathing, and a combined windiness index for each water use/yield response group (Fig. 3). The combined windiness index was computed as the product of maximum wind gust and daily average wind run during the week before swathing divided by 100 . A strong positive correlation (0.839) was seen between water use/yield regression slope and precipitation occurring during the week of 12-18 August. A strong negative correlation $(-0.947)$ was seen between water use/yield regression slope and number of days in July and August with Tmax $>36^{\circ} \mathrm{C}$. Weaker negative correlations were seen between water use/yield regression slopes and the wind parameters during the week before swathing. Because of previous research that acknowledged that increasing evaporative demand of an environment decreased the slope of the water use/yield relationship (Tanner and Sinclair, 1983; Musick et al., 1994; Stewart et al., 1977; Shantz and Piemeisel, 1927), we also checked the correlation of water use/yield slopes for the four response groups to July, August, and July-August pan evaporation (data not shown). We did not find any correlation between water use/yield slopes and pan evaporation in any period $(\mathrm{R}=-0.02$, July; $\mathrm{R}=-0.28$, August; $\mathrm{R}=-0.14$, July-August).

\section{Discussion}

All six of the parameters defining the regression equation (Equation 12, Table 5) make sense with regards to influencing proso millet yield. Previously reported research indicated that proso millet yield was related well to water use and plant available water at planting. It is also logical that millet yield would increase with increasing amounts of precipitation falling during the grain-filling period corresponding to the 12-18 August period. It also seems reasonable that high temperatures in July and August could reduce yields and that windy conditions during the week prior to swathing could result in seed shattering and yield loss. Other factors not included in the analysis that are important 


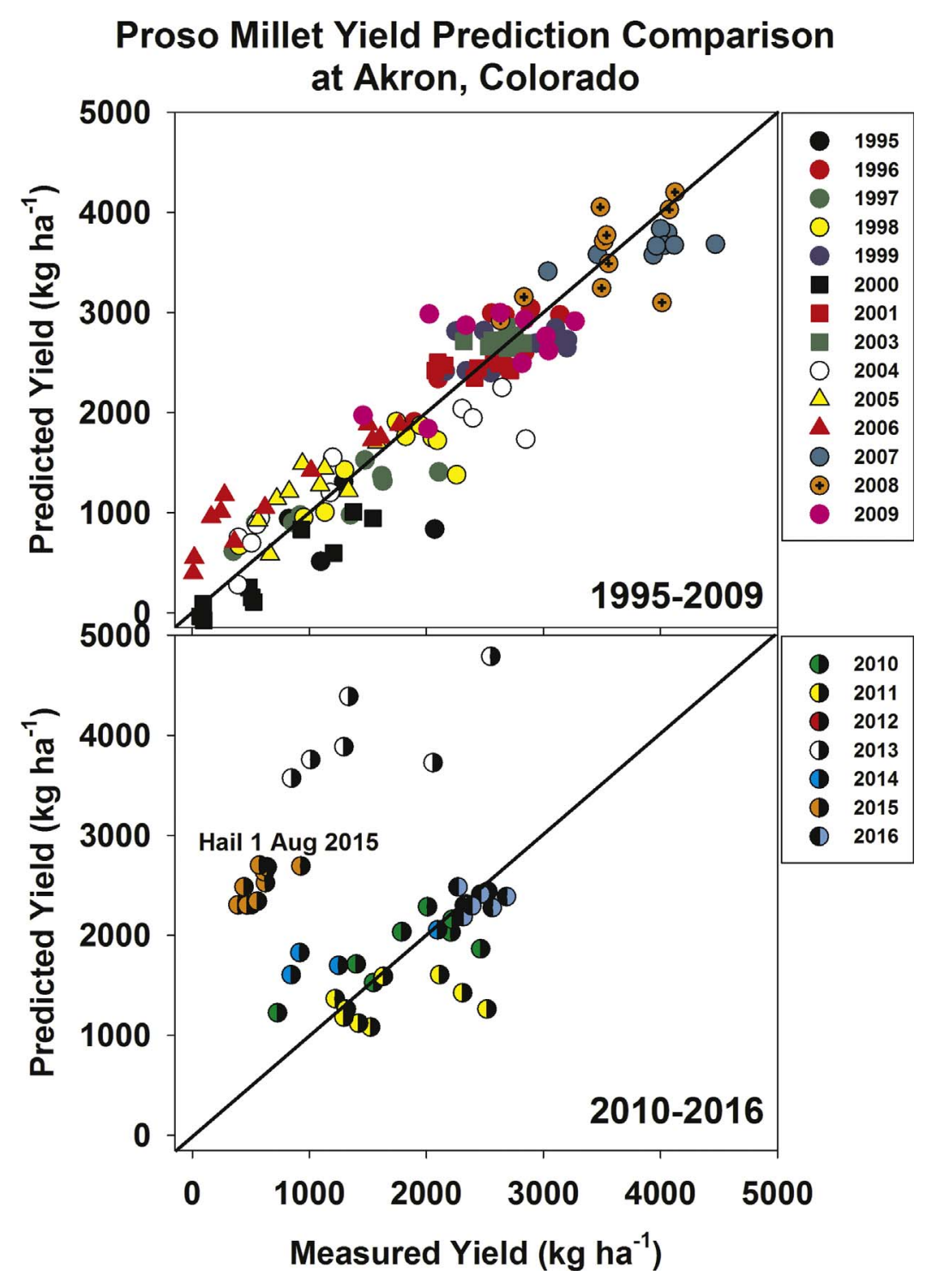

Fig. 2. Measured proso millet yield vs yield predicted by the six-parameter model identified in the text (1995-2009, upper panel; 2010-2016, lower panel) at Akron, CO. to final yield determination could be: poor plant stand because of restricted emergence due to heavy rains following planting producing crusting (Lyon et al., 2008) or stand loss due to hail; extended length of time between swathing and combining that could lead to additional seed loss; hail events that result in lodging or seed shattering.

It is not likely that the six-parameter regression model that was found to predict proso millet yields reasonably well in this study (Equation 12, Table 5) will be a useful prediction tool for farmers in this region because access to all of the necessary data is not easily obtained. However, when such data do exist they could be used with the regression model to construct yield cumulative probability exceedance graphs that farmers could use to assess production risk. An example is shown in Fig. 4 for Akron (top panel) constructed with weather data collected from 1984 through 2016 and assuming four levels of available soil water at planting. Growing season water use was estimated as the sum of growing season precipitation and the four levels of available soil water at planting. The weather data came from automated weather stations at each location (High Plains Regional Climate Center, available at http://awdn.unl.edu/classic/home.cgi, Accessed 1 April, 2017). The example shows that a proso millet yield of at least $2000 \mathrm{~kg} \mathrm{ha}^{-1}$ would be expected to occur $14 \%$ of the time with $25 \%$ plant available water at planting, $27 \%$ of the time with $50 \%$ plant available water at planting, $46 \%$ of the time with $75 \%$ plant available water at planting, and $65 \%$ of the time with $100 \%$ plant available water at planting. A similar graph Fig. 4, middle panel) was produced for Sidney, NE (115 km north of Akron) using weather data from 1986 through 2016 and showed that a proso millet yield of at least $2000 \mathrm{~kg} \mathrm{ha}^{-1}$ would be expected to occur $8 \%$ of the time with $25 \%$ plant available water at planting, $23 \%$ of the time with $50 \%$ plant available water at planting, $45 \%$ of the time with $75 \%$ plant available water at planting, and $70 \%$ of the time with $100 \%$ plant available water at planting. For McCook, NE (220 km east of Akron) the probabilities for exceeding $2000 \mathrm{~kg} \mathrm{ha}^{-1}$ yield were $16 \%$ of the time with $25 \%$ plant available water at planting, $29 \%$ of the time with $50 \%$ plant available water at planting, $40 \%$ of the time with $75 \%$ plant available water at planting, and $58 \%$ of the time with $100 \%$ plant available water at planting (Fig. 4, lower panel). The relative shapes of the cumulative probability exceedance graphs for Akron and Sidney correspond to those previously presented by Saseendran et al. (2013) from the results of a cropping systems modeling study, with somewhat lower probabilities of achieving a given 
Table 6

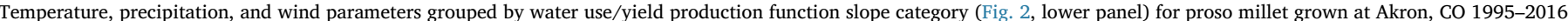

\begin{tabular}{|c|c|c|c|c|c|c|c|}
\hline $\begin{array}{l}\text { Water use/yield } \\
\text { category slope } \\
\text { category }\end{array}$ & Year & $\begin{array}{l}\text { \# days with } \\
\text { Tmax }>36^{\circ} \mathrm{C}\end{array}$ & $\begin{array}{l}\text { August 12-18 } \\
\text { Precipitation } \\
\mathrm{mm}\end{array}$ & $\begin{array}{l}\text { Maximum wind gust, } \\
\text { week before } \\
\text { swathing } \\
\mathrm{km} \mathrm{h}^{-1}\end{array}$ & $\begin{array}{l}\text { Daily average wind } \\
\text { run, week before } \\
\text { swathing } \\
\mathrm{km} \mathrm{day}^{-1}\end{array}$ & $\begin{array}{l}\text { Combined } \\
\text { windiness index }^{\mathrm{a}}\end{array}$ & $\begin{array}{l}\text { Water use/yield } \\
\text { production function slope } \\
\mathrm{kg} \mathrm{ha}^{-1} \mathrm{~mm}^{-1}\end{array}$ \\
\hline \multirow[t]{4}{*}{ High } & 1997 & 8 & 7 & 53.6 & 264.5 & 141.8 & \\
\hline & 2007 & 8 & 47 & 40.2 & 334.3 & 134.4 & \\
\hline & 2009 & 0 & 70 & 55.8 & 308.6 & 172.2 & \\
\hline & Average & 5.3 & 41 & 49.9 & 302.5 & 150.9 & 33.62 \\
\hline \multirow[t]{7}{*}{ Medium } & 1995 & 19 & 0 & 43.6 & 346.5 & 151.1 & \\
\hline & 1998 & 8 & 3 & 38.3 & 384.4 & 147.2 & \\
\hline & 1999 & 4 & 0 & 51.2 & 248.1 & 127.0 & \\
\hline & 2001 & 8 & 14 & 55.8 & 266.5 & 148.7 & \\
\hline & 2008 & 11 & 65 & 47.6 & 288.3 & 137.2 & \\
\hline & 2013 & 4 & 53 & 40.4 & 273.5 & 110.5 & \\
\hline & Average & 9.0 & 23 & 46.2 & 301.2 & 139.2 & 17.88 \\
\hline \multirow[t]{9}{*}{ Low } & 1996 & 4 & 15 & 56 & 312.6 & 175.1 & \\
\hline & 2000 & 4 & 9 & 60.3 & 302.5 & 182.4 & \\
\hline & 2003 & 17 & 4 & 47.6 & 285.2 & 135.8 & \\
\hline & 2004 & 8 & 0 & 52.9 & 302.6 & 160.1 & \\
\hline & 2006 & 12 & 3 & 44.2 & 331.4 & 146.5 & \\
\hline & 2010 & 5 & 6 & 49.4 & 371.7 & 183.6 & \\
\hline & 2011 & 12 & 0 & 50.0 & 339.5 & 169.8 & \\
\hline & 2016 & 7 & 0 & 49.2 & 325.0 & 159.9 & \\
\hline & Average & 8.6 & 5 & 51.2 & 321.3 & 164.5 & 15.66 \\
\hline \multirow[t]{6}{*}{ Very low } & 2005 & 12 & 20 & 59.9 & 299.9 & 179.6 & \\
\hline & 2012 & 21 & 1 & 46.5 & 366.9 & 170.6 & \\
\hline & 2014 & 6 & 25 & 61.6 & 259.1 & 159.6 & \\
\hline & $2015^{\mathrm{b}}$ & 3 & 42 & 66.6 & 178.4 & 118.8 & \\
\hline & Average & 10.5 & 22 & 58.7 & 276.1 & 162.1 & \\
\hline & $\begin{array}{l}\text { Average } \\
\text { without } 2015\end{array}$ & 13.0 & 15 & 56.0 & 308.6 & 172.8 & 8.37 \\
\hline
\end{tabular}

${ }^{\text {a }}$ Combined windiness index $=($ Maximum wind gust X Daily average wind run $) / 100$.

${ }^{\mathrm{b}}$ Hail storm, 1 August 2015.

yield at Sidney than at Akron. However, the probabilities that they presented for achieving a given proso millet yield at $75 \%$ and $100 \%$ available water at planting were much greater than the probabilities shown in Fig. 4, presumably because the cropping systems model had no ability to simulate shattering losses that likely occur with windy conditions the week prior to swathing. It is also unknown as to whether the cropping systems model was adequately accounting for the detrimental effects of high temperature stress in July and August.

Perhaps the most important result of the stepwise linear regression analysis performed in the current study is that the important factors influencing proso millet yield have been confirmed. Water use, plant available water at planting, and precipitation from 12 to 18 August increase yield, while daily maximum temperatures greater than $36{ }^{\circ} \mathrm{C}$ in July and August and windy conditions in the week preceding swathing decrease yield.

An advantage of having a long-term record such as analyzed in this study is the ability to estimate the probability of proso millet yield responding according to a certain production function. From the data presented in Table 5 we can calculate that the high water use/yield response with a slope of $33.62 \mathrm{~kg} \mathrm{ha}^{-1} \mathrm{~mm}^{-1}$ would be applicable in three out of 22 years ( $13.6 \%$ of the time); the medium water use/yield response with a slope of $17.88 \mathrm{~kg} \mathrm{ha}^{-1} \mathrm{~mm}^{-1}$ would be applicable in six out of 22 years $(27.3 \%$ of the time); the low water use/yield response with a slope of $15.04 \mathrm{~kg} \mathrm{ha}^{-1} \mathrm{~mm}^{-1}$ would be applicable in eight out of 22 years (36.4\% of the time); the very low water use/yield response with a slope of $8.37 \mathrm{~kg} \mathrm{ha}^{-1} \mathrm{~mm}^{-1}$ would be applicable in 4 out of 22 years ( $18.2 \%$ of the time); and one year out of 22 years ( $4.6 \%$ of the time) a total crop failure could be expected.

\section{Conclusions}

A water-limited yield relationship was defined for Akron, CO, from a broad range of water use and yield data over a period of 22 years. The slope of this relationship ( $32.57 \mathrm{~kg} \mathrm{ha}^{-1}$ per mm of water use) is what would be expected for a C4 plant species in this region, but greater than previously reported as a water use/yield production function for northeast Colorado. Stepwise linear regression identified six parameters that strongly influenced yield. The regression was found to predict yields well in most years. The regression parameters identified as important to predicting proso millet yield suggest that plant breeding efforts should be directed towards improving shattering resistance and heat tolerance and that cropping systems management changes should be directed towards crop sequencing and no-till production methods that increase surface crop residues that improve precipitation storage during the non-crop period prior to proso millet planting to maximize available soil water at millet planting.

\section{Disclaimer}

Mention of trade names or commercial products in this publication is solely for the purpose of providing specific information and does not imply recommendation or endorsement by the U.S. Department of Agriculture.

The U.S. Department of Agriculture (USDA) prohibits discrimination in all its programs and activities on the basis of race, color, national origin, age, disability, and where applicable, sex, marital status, familial status, parental status, religion, sexual orientation, genetic information, 

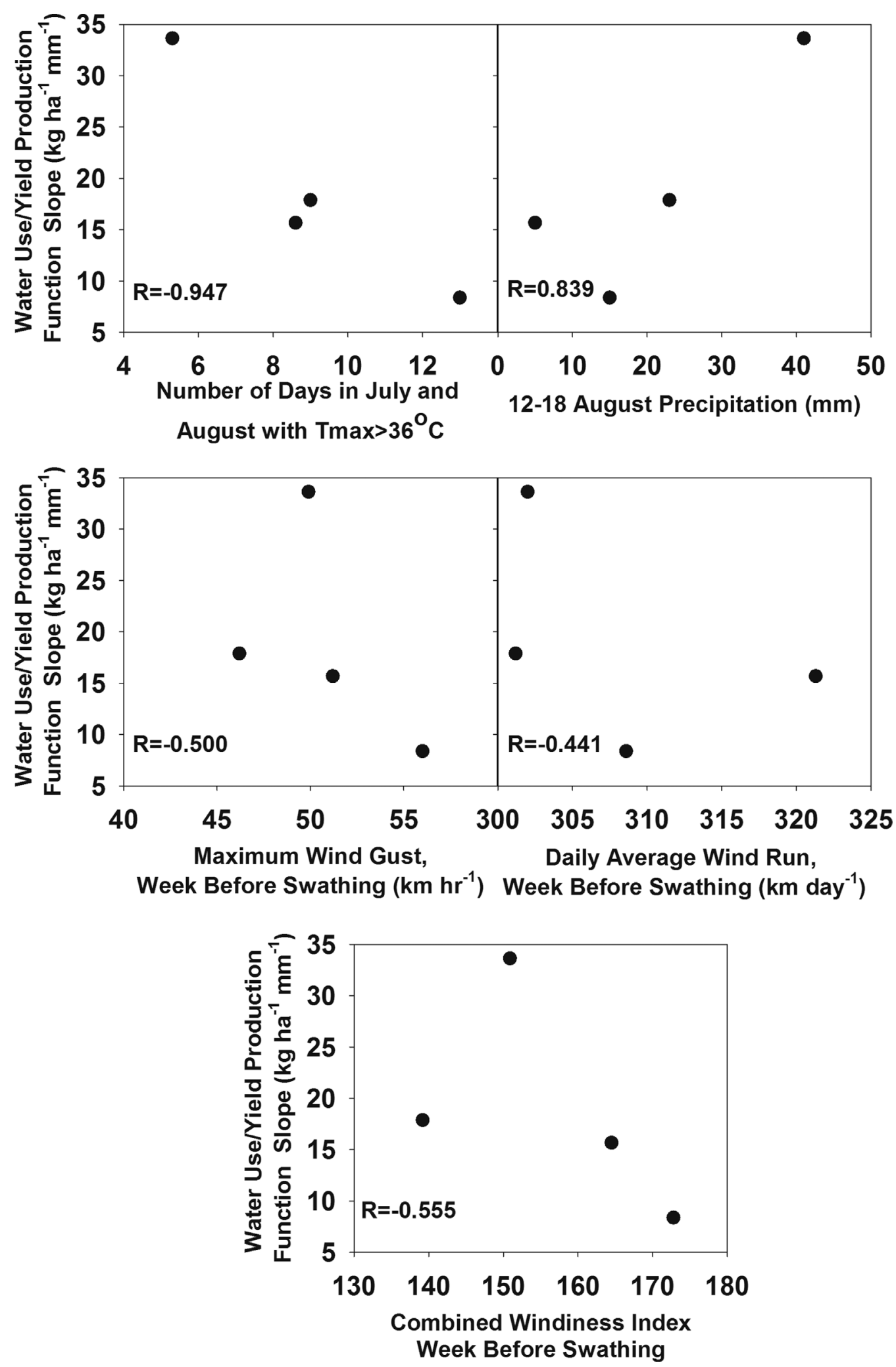

political beliefs, reprisal, or because all or part of an individual's income is derived from any public assistance program. (Not all prohibited bases apply to all programs.) Persons with disabilities who require alternative means for communication of program information (Braille, large print, audiotape, etc.) should contact USDA's TARGET Center at (202) 7202600 (voice and TDD). To file a complaint of discrimination, write to
Fig. 3. Correlation between proso millet water use/yield production function slope and number of days in July and August with maxmium temperature (Tmax) greater than $36{ }^{\circ} \mathrm{C}$, precipitation from 12 to 18 August, maximum wind gust during the week before swathing, daily average wind run during the week before swathing, and a combined windiness index for four response groups at Akron, CO, 1995-2016. 


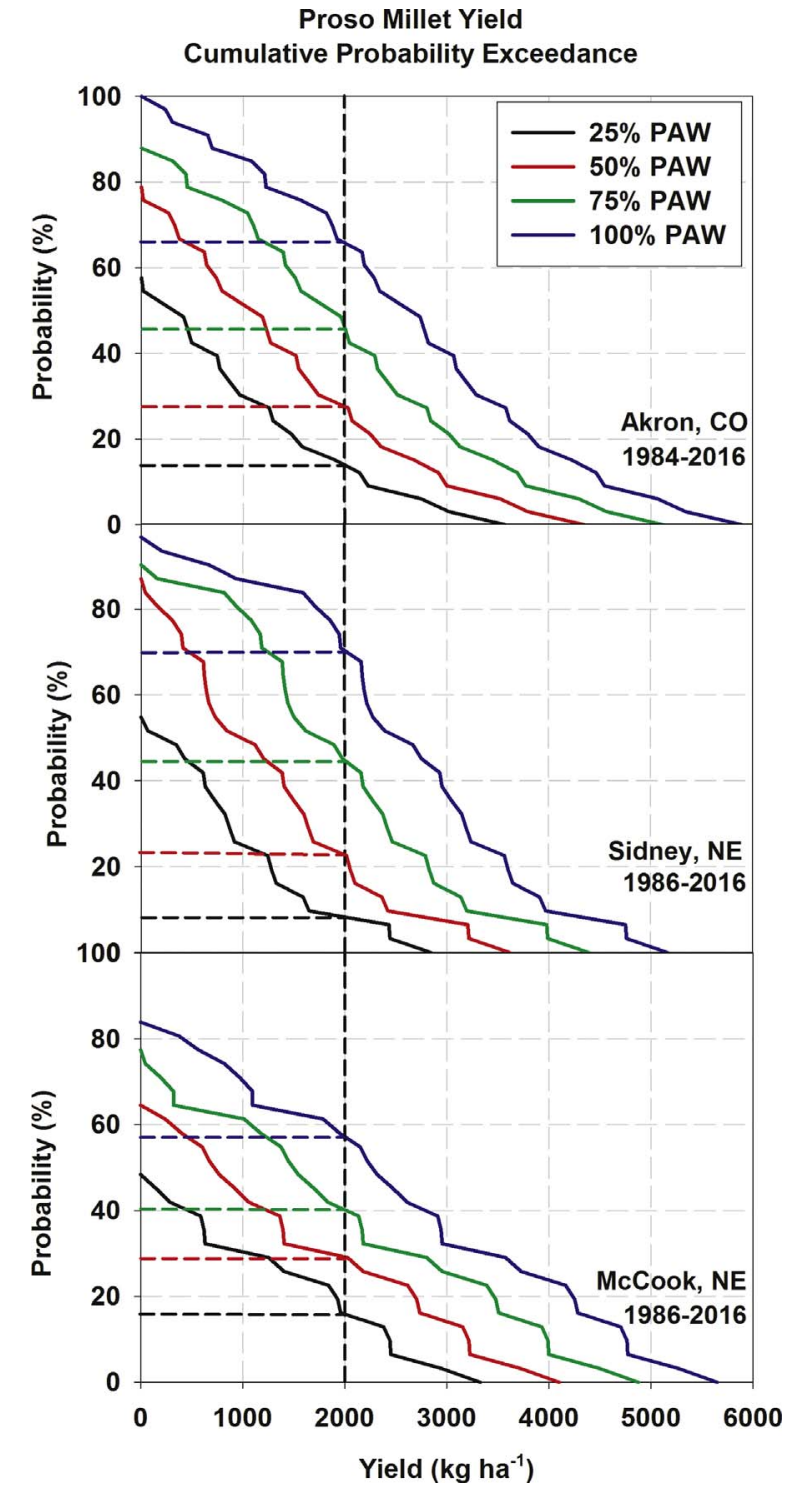

Fig. 4. Proso millet yield cumulative probability exceedance graphs for Akron, CO; Sidney, NE; and McCook, NE.

\section{Acknowledgements}

The authors express their sincere gratitude for help with plot preparation, maintenance, and data collection to Delbert Koch, David Poss, Paul Campbell, Gene Uhler, Bob Florian, Kurt Reule, Ken Fetzer, Cody Hardy, Linda Hardesty, Albert Figueroa, Jamie Sauer, Martin Walker, Karen Couch, Mike Kundert, Mike Perry, Liza Slusser, Anna Shannon, Erin Jefferson, Gordon Nielsen, Ben Nielsen, Katie Strand, Garrick Friedley, Taylor Krause, Morgan Woods, Shelby Guy, Alexis Thompson, Shelby Dunker, Kiara Guy, and Kelsey Guy. Special recognition goes to Tawney Bleak Campbell for outstanding assistance with data analysis and presentation.

\section{References}

Anderson, R.L., Bowman, R.A., Nielsen, D.C., Vigil, M.F., Aiken, R.M., Benjamin, J.G., 1999. Alternative crop rotations for the central great plains. J. Prod. Agric. 12, 95-99. Angus, J.F., van Herwaarden, A.F., 2001. Increasing water use and water use efficiency in dryland wheat. Agron. J. 93, 290-298. http://dx.doi.org/10.2134/agronj2001. 932290x.
Baltensperger, D.D., Nelson, L.A., Frickel, G.E., Anderson, R.L., 1995. Registration of Huntsman proso millet. Crop Sci. 35, 941.

Baltensperger, D.D., 1996. Foxtail and proso millet. In: Janick, J. (Ed.), Progress in New Crops. ASHS Press, Alexandria, VA, pp. 182-190.

Berglund, D.R., 2007. Proso Millet in North Dakota. Publication A-805. North Dakota State University, Fargo(available online at https://www.ag.ndsu.edu/crops/othercrops/2007-proso-millet).

Bowman, R.A., Halvorson, A.D., 1997. Crop rotation and tillage effects on phosphorus distribution in the Central Great Plains. Soil Sci. Soc. Am. J. 61, 1418-1422.

Emendack, Y., Herzog, H., Götz, K.-P., Malinowskim, D.P., 2011. Mid-season water stress on yield and water use of millet (Panicum miliaceum) and sorghum (Sorghum bicolor L Moench). Aust. J. Crop Sci. 5, 1486-1492.

Felter, D.G., Lyon, D.J., Nielsen, D.C., 2006. Evaluating crops for a flexible summer cropping system. Agron. J. 98, 1510-1517. http://dx.doi.org/10.2134/agronj2005. 0341.

French, R.J., Schultz, J.E., 1984. Water use efficiency of wheat in a Mediterranean-type environment I. The relation between yield, water use and climate. Aust. J. Agric. Res. 35, 743-764. http://dx.doi.org/10.1071/AR9840743.

Grossi, M.C., Justino, F., de Avila Rodrigues, R., Andrade, C.L.T., 2015. Sensitivity of sorghum yield to individual changes in climate parameters: modelling based approach Bragantia. Campinas 74, 341-349. http://dx.doi.org/10.1590/1678-4499. 0411.

Habiyaremye, C., Matanguihan, J.B., Guedes, J.D., Ganjyal, G.M., Whiteman, M.R., Kidwell, K.K., Murphy, K.M., 2017. Proso millet (Panicum miliaceum L.) and its potential for cultivation in the Pacific Northwest, U.S.: a review. Front. Plant Sci. 7 , 1961. http://dx.doi.org/10.3389/fpls.2016.01961.

Kirkegaard, J.A., Hunt, J.R., 2010. Increasing productivity by matching farming system management and genotype in water limited environments. J. Exp. Bot. 61 , 4129-4143. http://dx.doi.org/10.1093/jxb/erq245.

Lyon, D.J., Boa, F., Arkebauer, T.J., 1995. Water-yield relations of several spring planted dryland crops following winter wheat. J. Prod. Agric. 8, 281-286.

Lyon, D.J., Burgener, P.A., DeBoer, K.L., Harveson, R.M., Hein, G.L., Hergert, G.W., Holman, T.L., Nelson, L.A., Johnson, J.J., Nleya, T., Krall, J.M., Nielsen, D.C., Vigil, M.F., 2008. Producing and Marketing Proso Millet in the Great Plains. Publication \# EC137. Univ. of Nebraska Coop. Ext. Serv., Lincoln, NE.

Ma, L., Ahuja, L.R., Saseendran, S.A., Malone, R.W., Green, T.R., Nolan, B.T., Bartling, P.N.S., Flerchinger, G.N., Boote, K.J., Hoogenboom, G., 2011. A protocol for parameterization and calibration of RZWQM2 in field research. In: Ahuja, L.R., Ma, L. (Eds.), Methods of Introducing System Models into Agricultural Research, edition 2. ASA, CSSA, SSSA, Madison, WI, pp. 1-64. http://dx.doi.org/10.5499/wjr.v1.i1.1.

Ma, L., Trout, T.J., Ahuja, L.R., Bausch, W.C., Saseendran, S.A., Malone, R.W., Nielsen, D.C., 2012. Calibrating RZWQM2 model for maize responses to deficit irrigation. Agric. Water Manage. 103, 140-149. http://dx.doi.org/10.1016/j.agwat.2011.11. 005.

Matsuura, A., Tsuji, W., An, P., Inanaga, S., Murata, K., 2012. Effect of pre- and postheading water deficit on growth and grain yield of four millets. Plant Prod. Sci. 15, 323-331. http://dx.doi.org/10.1626/pps.15.323.

Musick, J.T., Jones, O.R., Stewart, B.A., Dusek, D.A., 1994. Water-yield relationships for irrigated and dryland wheat in the U. S. Southern Plains. Agron. J. 86, 980-986.

Nelson, L.A., Fenster, C.R., 1983. Seedbed preparation and planter comparisons for proso millet following wheat. Agron. J. 75, 9-13.

Nelson, L.A., 1990. Registration of sunup proso millet. Crop Sci. 30, 746-747.

Nielsen, D.C., Vigil, M.F., 2010. Precipitation storage efficiency during fallow in wheatfallow systems. Agron. J. 102, 537-543.

Nielsen, D.C., Vigil, M.F., 2017. Defining a dryland grain sorghum production function for the Central Great Plains. Agron. J. 109http://dx.doi.org/10.2134/agronj2017.3. 0131. (published online, 1 June 2017).

Nielsen, D.C., Vigil, M.F., Benjamin, J.G., 2011. Evaluating decision rules for dryland rotation crop selection. Field Crops Res. 120, 254-261. http://dx.doi.org/10.1016/j. fcr.2010.10.011.

Nielsen, D.C., Lyon, D.J., Hergert, G.W., Higgins, T.K., Holman, J.D., 2015. Cover crop biomass production and water use in the Central Great Plains. Agron. J. 107, 2047-2058. http://dx.doi.org/10.2134/agronj15.0186.

Ratliff, L.R., Ritchie, J.T., Cassel, D.K., 1983. A survey of field-measured limits of soil water availability and related laboratory-measured properties. Soil Sci. Soc. Am. J. 47, 770-775.

Ritchie, J.T., 1981. Soil water availability. Plant Soil 58, 327-338.

Sadras, V.O., Angus, J.F., 2006. Benchmarking water-use efficiency of rainfed wheat in dry environments. Aust. J. Agric. Res. 57, 847-856. http://dx.doi.org/10.1071/ AR05359.

Saseendran, S.A., Nielsen, D.C., Ma, L., Ahuja, L.R., Vigil, M.F., 2010. Simulating alternative dryland rotational cropping systems in the Central Great Plains with RZWQM2. Agron. J. 102, 1521-1534. http://dx.doi.org/10.2134/agronj2010.0141.

Saseendran, S.A., Nielsen, D.C., Ahuja, L.R., Ma, L., Lyon, D.J., 2013. Simulated yield and profitability of five potential crops for intensifying the dryland wheat-fallow production system. Agric. Water Manage. 116, 175-192. http://dx.doi.org/10.1016/j agwat.2012.07.009.

Seghatoleslami, M.J., Kafi, M., Majidi, E., 2008. Effect of drought stress at different growth stages on yield and water use efficiency of five proso millet (Panicum miliaceum L.) genotypes. Pak. J. Bot. 40, 1427-1432.

Shanahan, J.F., Anderson, R.L., Greb, B.W., 1988. Productivity and water use of proso millet grown under three crop rotations in the Central Great Plains. Agron. J. 80, 487-492.

Shantz, H.L., Piemeisel, L.N., 1927. The water requirement of plants at Akron, Colo. J. Agric. Res. 34, 1093-1190.

Stewart, J.I., Danielson, R.E., Hanks, R.J., Jackson, E.B., Hagan, R.M., Pruitt, W.O., 
Franklin, W.T., Riley, J.P., 1977. Optimizing Crop Production Through Control of Water and Salinity Levels in the Soil. Utah Water Lab. Pub. No. PRWG 151-1, Logan (available at http://digitalcommons.usu.edu/cgi/viewcontent.cgi?article $=1066 \&$ context $=$ water_rep).

Tanner, C.B., Sinclair, T.R., 1983. Efficient water use in crop production: research or re- search? In: Taylor, H.M., Jordon, W.R., Sinclair, T.R. (Eds.), Limitations to Efficient Water Use in Crop Production. ASA, CSSA, SSSA, Madison, WI, pp. 1-27. http://dx. doi.org/10.2134/1983.limitationstoefficientwateruse.c1.

Willmott, C.J., 1984. On the evaluation of model performance in physical geography. Spatial Stat. Models 40, 443-460. 